\title{
Recorregut de recerca geològica i mineralògica per les comarques del Baix Camp i del Priorat: des del Coll Roig de Pratdip, a Pratdip, Colldejou i a la Torre de la Fontaubella
}

Josep Maria Mata-Perelló

Joaquim Sanz Balagué

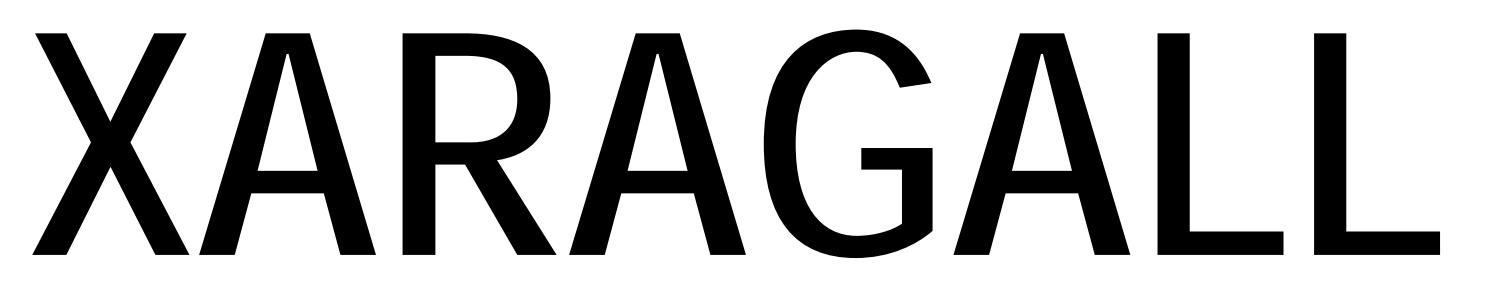

REVSTA DE CIE்NCIES DEE LA CATALUNYA CENTRAL

\section{n. 2}

FEBRER 2015 


\title{
RECORREGUT DE RECERCA GEOLÒGICA I MINERALÒGICA PER LES COMARQUES DEL BAIX CAMP I DEL PRIORAT: DES DEL COLL ROIG DE PRATDIP, A PRATDIP, COLLDEJOU I A LA TORRE DE LA FONTAUBELLA
}

\author{
Josep Maria Mata-Perelló \\ Museu de geologia Valentí Masachs, Escola Politècnica Superior d'Enginyeria de Manresa \\ (EPSEM), Universitat Politècnica de Catalunya · BarcelonaTech (UPC), 08272 Manresa, Spain
}

\section{Joaquim Sanz Balagué}

Departament d'Enginyeria Minera i Recursos Naturals (EMRN), Escola Politècnica Superior d'Enginyeria de Manresa (EPSEM), Universitat Politècnica de Catalunya . BarcelonaTech (UPC), 08272 Manresa, Spain

Paraules clau: Sistema Mediterrani, Patrimoni miner

\section{Resum}

Itinerari realitzat el 6 d'abril de 2014. En aquesta ocasió, el recorregut de l'itinerari discorrerà, en la seva major part pel Sistema Mediterrani (i més concretament per la seva subunitat més interna, la Serralada Prelitoral Catalana). Així, discorrerà pràcticament entre les immediacions de la localitat de Pratdip (Baix Camp) i les proximitats de la de la Torre de Fontaubella (Priorat). Així doncs, el recorregut de l'itinerari s'iniciarà a la Serralada Prelitoral Catalana, per la qual es circularà, en tota la resta del recorregut, entre les immediacions de les dues localitats abans esmentades.

Per altra banda el recorregut s'iniciarà dintre de la comarca del Baix Camp (a Pratdip), per a finalitzar a la comarca del Priorat (per les immediacions de Falset). Es passarà de la primera a la segona comarca al Coll Roig, entre Colldejou i la Torre de la Fontaubella. 


\section{Objectius fonamentals}

Al llarg del recorregut del present itinerari, esperem aconseguir els següents objectius, esmentats d'acord amb el sentit de la marxa:

1. Estudi i observació dels materials paleozoics (del Carbonífer, fonamentalment), que constitueixen la Serralada Prelitoral Catalana. L'itinerari discorrerà per entre aquests materials al final del recorregut, especialment pels voltants de Marçà (Priorat). Així, en aquests indrets afloren els materials granítics del Carbonífer.

2. Estudi i observació dels materials mesozoics (del Triàsic, del Juràssic i del Cretàcic), que formen part de la Serralada Prelitoral Catalana. aquests materials els i trobarem a la major part del recorregut de l'itinerari, entre les immediacions de Pratdip (Baix Camp) i les den la Torre de la Fontaubella (comarca del Priorat).

3. Estudi de l'estructura de la Serralada Prelitoral Catalana, al llarg de tot el recorregut de l’itinerari.

4. Observació d'algunes explotacions mineres, que s'aniran trobant al llarg del recorregut de l’itinerari.

5. Observació de l'impacte produït sobre el Medi Natural, per les explotacions anteriors. I si s'escau de les restauracions dutes a terme per tal d'evitar-ho.

6. Observació i valorització de diferents aspectes del recorregut estretament relacionats amb el Patrimoni Geològic i Miner.

\section{Antecedents}

Existeixen una sèrie $d^{\prime}$ antecedents nostres, pel que fa als itineraris geològics i mineralògics, que discorren per aquestes terres. Es tracta de: Mata Perelló (1996a, 1996b, 1996c, 1997, 1998, 2000, 2001, 2004a, 2004b, 2008a, 2008b, 2011a, 2011b, 2011c i 2012). Tret d'aquestes no en coneixem cap altres itineraris que passin per aquestes terres.

Pel que fa a l'estudi de les mineralitzacions situades al llarg del recorregut, farem un especial esment del treball de Melgarejo i Draper (1992), relatiu a les mineralitzacions que s'estenen per les comarques per les quals discorre el recorregut de l'itinerari. També farem esment, pel que fa als antecedents de caire mineralògic, d'un altre treball, en aquest cas nostre, Mata Perelló (1991), relatiu al conjunt de les mineralitzacions catalanes. I, pel que fa a l'estructura geològica dels indrets pels quals discorrerà el recorregut de l'itinerari, farem esment de dos treballs generals, relatius al conjunt dels Països Catalans: Guimerà et altri (1992), i Riba et altri (1976). En aquest aspecte, també farem esment de les publicacions de l'IGME (1978).

Tots aquests treballs esmentats, figuraran per ordre alfabètic a l'apartat dedicat a la bibliografia. 


\section{Recorregut de l'itinerari}

El recorregut d'aquest itinerari comença prop de la població de Pratdip, al Baix Camp. En aquest indret es realitzarà una parada. Tot seguit, el recorregut es dirigirà cap a llevant, anant cap al poble de Pratdip i cap a Colldejou. En aquest trajecte es faran dues parades; i també una petita fillola, si s'escau, per tal de fer una altra parada al Coll de la Llena. En aquest recorregut, s' haurà circulat per les carreteres T - 311 i després per la T - 322.

Després, i per la carretera darrerament esmentada, s'anirà cap a la Torre de la Fontaubella. En aquest recorregut, es faran diverses parades. Per d'altra banda, en arribar al terme de la Torre de la Fontaubella, es deixa la comarca del Baix Camp, i es penetra a la del Priorat.

\section{Advertiments previs}

Com en altres recorreguts de RECERCA GEOLÒGICA I MINERALÒGICA... si es disposa del temps suficient, poden efectuar-se passant per totes les parades i filloles. En cas contrari, recomanem reestructurar el recorregut, prescindint de les anomenades PARADES CONDICIONALS, i d'altres si s'escau.

També recomanem de cercar la informació més adient, sobre els trams a recórrer mitjançant camins de terra, o de pista. Precisament, en aquest itinerari, hi ha alguns trajectes d'aproximació cap a les mines, que haurem de fer per camins de terra en irregular estat de conservació.

Per altra banda, recomanem tenir una cura extrema de la NATURA, evitant qualsevol forma d'agressió sobre ella, o de fer-n'hi un mal ús del que en ofereix la nostra mare Terra.

\section{Descripció de l'itinerari}

Com en altres itineraris, a continuació veurem una sèrie de "parades o estacions". En cada una d'elles es farà un breu comentari. Per d'altra banda, darrera del nom de l'indret (o de la parada), situarem entre parèntesi el número del Mapa Topogràfic, a escala 1:50.000, on es troba l'indret de l'aturada. En aquesta ocasió, utilitzarem solament dos fulles de l'esmentat mapa topogràfic; concretament el full $\mathbf{4 7 1}$ (dit de Mora d’Ebre), i el full $\mathbf{4 7 2}$ (dit de Reus).

Així doncs, la relació ordenada, de les parades que composen el recorregut d'aquest itinerari. és la següent: 


\subsection{Parada 1. COLL ROIG DE PRATDIP, (terme municipal de Pratdip, comarca del Baix Camp). (Full 472).}

Cal iniciar el recorregut de l'itinerari, en aquest indret, que es troba a la cruilla de la carretera $T$ - 311 (que uneix Tivissa amb Pratdip) amb la condueix cap a Llaberia (la TV - 3111). En aquest indret, del terme de Pratdip, realitzarem la primera aturada.

En aquest indret afloren els nivells guixosos i els calcolutítics rogencs del Muschelkalk Mig. Molt ocasionalment, la carretera ha entrat (pel Sud), entre els afloraments carbonatats del Muschelkalk Inferior, els quals formen part de l'Àrea d'encavalcaments de Pratdip, i més concretament de la Serra de Santa Marina. Precisament, aquests són els materials que es troben a l'indret on ara som (la qual cosa ja queda reflectida a la pròpia toponímia).

\subsection{Parada 2. IMMEDIACIONS DE PRATDIP, (terme municipal de Pratdip, comarca del Baix Camp). (Full 472).}

Després de realitzar la parada anterior, cal efectuar un recorregut proper als $6 \mathrm{Km}$, per la carretera T - 311, amb la intenció d'arribar fins al proper poble de Pratdip. Quasi en arribar-hi, realitzarem una nova aturada, a menys de $1 \mathrm{Km}$ del poble.

En aquest recorregut, haurem trobat afloraments dels materials esmentats a l'aturada anterior, els quals pertanyen al Triàsic i concretament al Muschelkalk Mig. Per d'altra banda, al Sud de Pratdip (a la Serra de Cabrafiga), es fan palesos els afloraments carbonatats del Muschelkalk Inferior. (fotografia 1).

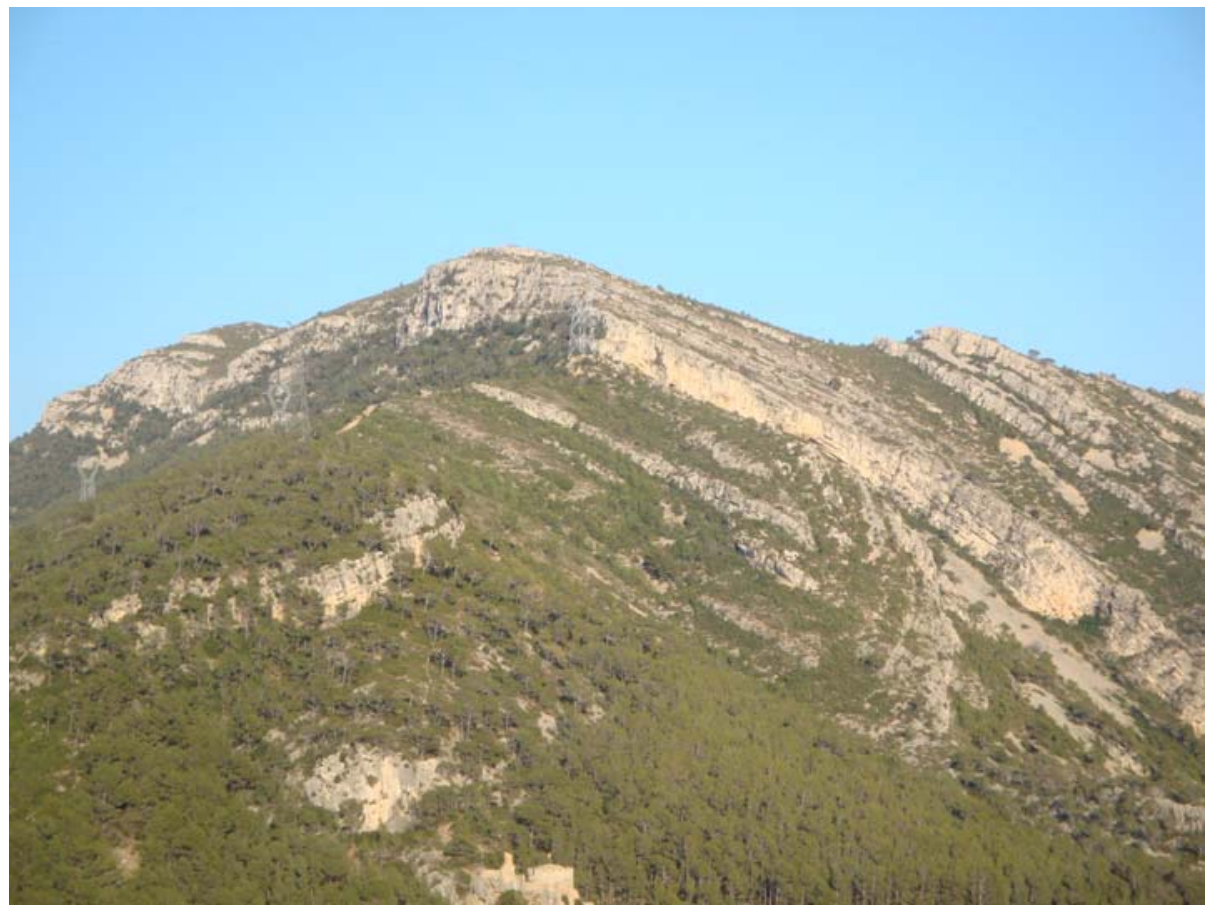

Fotografia 1. La Serra de Cabrafiga a llevant de Pratdip. Pot intuir-se tanmateix la Falla de Pratdip 


\subsection{Parada 3. FORN D'OBRA DEL TRENCALL DE LA CARRETERA AL COLL DE LA LLENA, (terme de Pratdip, comarca del Baix Camp). (Full 472).}

Des de la parada anterior, cal continuar per la carretera que es dirigeix cap al proper poble de Pratdip, la T - 311. Just en arribar-hi i prendre la carretereta que es dirigeix cap al Coll de la Llena i cap a Colldejou, farem una nova aturada a la bora de la mateixa cruïlla. Així, des de la parada anterior, haurem recorregut poc menys de $1 \mathrm{Km}$.

En aquest recorregut, haurem trobat afloraments dels materials esmentats a la parada anterior, sobre els quals s'assenta el poble de Pratdip. Es tracta dels nivells de calcotutites rogenques del Muschelkalk Mig. Per d'altra banda, al Sud d'aquests es troben afloraments dels materials carbonatats del Muschelkalk Inferior.

En aquest indret hi ha les restes d'un antic forn d'obra (forn de teules). Aquest es troba en un estat lleugerament ruïnós (i amb diverses escombraries), tot i que encara podria recuperar-se (fotografía 2). Tot i així, aquest element forma part del patrimoni miner de la comarca del Baix Camp.

Possiblement, en aquest forn s'utilitzaven les calcolutites estretes més amunt, al costat de la carretera que condueix cap a Colldejou (PARADA 4)

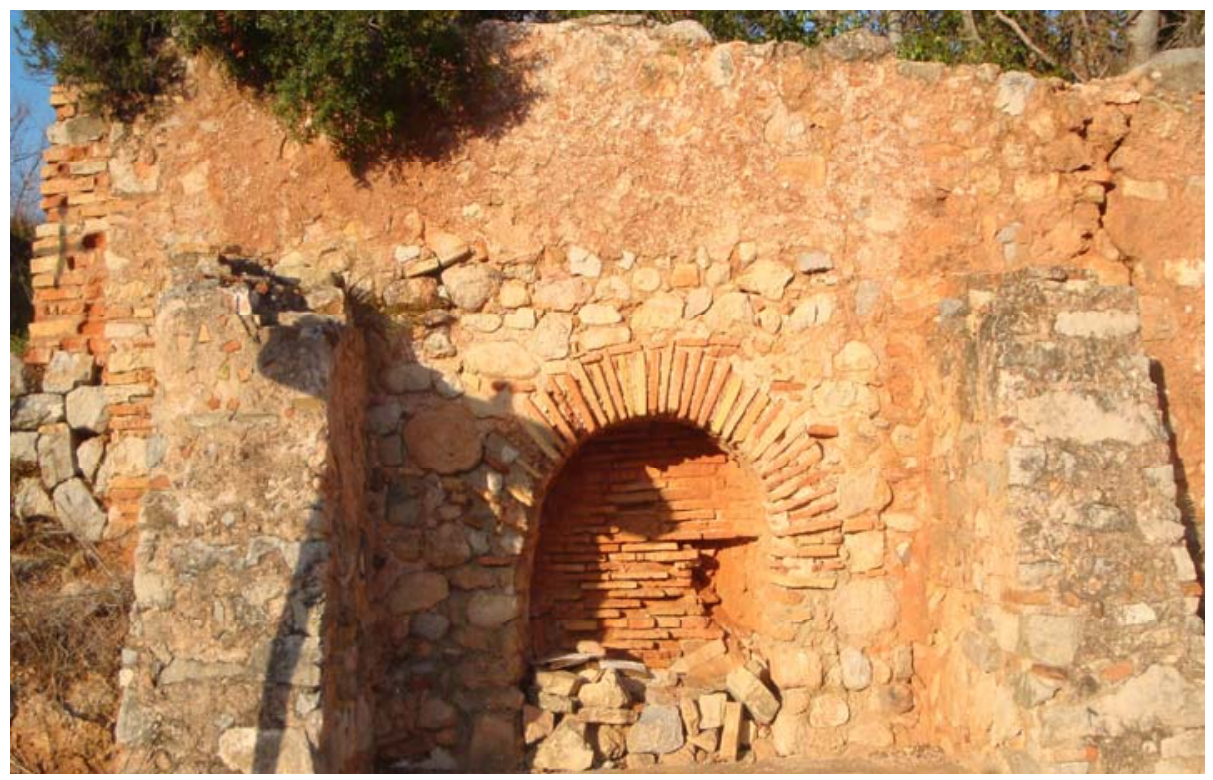

Fotografia 2. Forn d'obra. Pratdip 


\subsection{Parada 4. EXPLOTACIÓ DE CALCOLUTITES I ESLLAVISSADA. CARRETERA A COLLDEJOU I AL COLL DE LA LLENA, (terme de Pratdip, comarca del Baix Camp). (Full 472).}

Des de la parada anterior, cal sortir de Pratdip per la carretera que es dirigeix cap al Coll de la Llena i cap a Colldejou. A poc més de $1^{\prime} 5 \mathrm{Km}$, farem una nova aturada, dintre del recorregut d'aquest itinerari.

En tot aquest trajecte, hem anat trobant afloraments dels materials triàsics del Muschelkalk Mig, amb nivells de calcolutites rogenques i guixos. Per sobre s'han anat fen palesos els trams carbonatats del Muschelkalk Superior. Alhora que per sota, haurem vist (a la Serra de Cabrafiga) afloraments dels trams carbonatats del Muschelkalk Inferior.

Prop d'on ara som (en un tram ascendent de la carretera), haurem vist una antiga explotació dels nivells calcolutítics rogencs. Es tracta d'una explotació de grans dimensions situada a la bora de la carretera.

Per altra banda, per sobre de l'explotació de calcolutites es pot observar una esllavissada dels materials carbonatats del Muschelkalk Superior. Molt possiblement, aquesta s' ha produït com a conseqüència de sa sobreexcavació de les calcolutites que es troben per sota dels nivells carbonatats. Per d'altra banda, cal considerar que les calcaries i dolomies del Muschelkalk Superior, constitueixen un nivell molt competent, situat per sobre d'altres més incompetent (les calcolutites del Muschelkalk Mig), que si encara han estat sobreexcavades, pitjor encara. Així, com a conseqüència d'aquesta situació s'ha produït una interessant esllavissada. (fotografia 3).

Per altra banda, aquest moviment i aquesta inestabilitat, han arribat fins a la mateixa carretera, on aparegut esquerdes, amb la mateixa direcció que I'esllavissada. Clar que la carretera discorre entre I'antiga explotació de les calcolutites (per l'esquerra en sentit ascendent) i un barranc situat a la dreta de la mateixa. Creiem, sense cap mena de dubte que la carretera pateix d'una certa inestabilitat. 


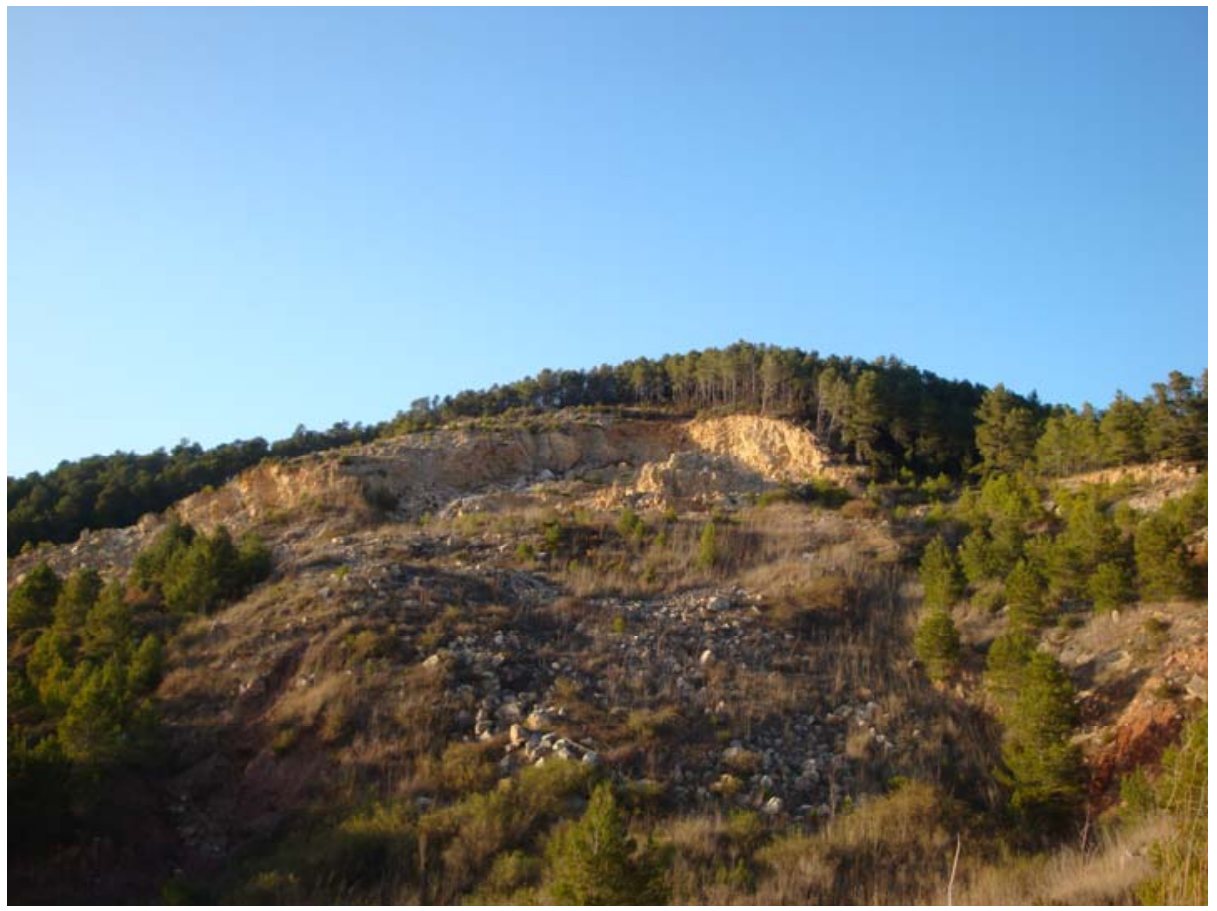

Fotografia 3. Esllavissada de les calcàries del Muschelkalk Superior, sobre les calcolutites rogenques del Muschelkalk Mig

\subsection{Parada 5. COLL DEL GUIX. EXPLOTACIÓ DE GUIXOS I FORNS DE GUIXES. CARRTERA A COLLDEJOU I AL COLL DE LA LLENA, (termes de Pratdip i de Colldejou, comarca del Baix Camp). (Full 472).}

Des de la parada anterior, cal continuar per la carretera que es dirigeix cap al Coll de la Llena i cap a Colldejou. A poc més de $2^{\prime} 5 \mathrm{Km}$, farem una nova aturada, dintre del recorregut d'aquest itinerari. La farem al conegut Coll del Guix.

Com al cas anterior, en tot aquest trajecte, hem anat trobant afloraments dels materials triàsics del Muschelkalk Mig, amb nivells de calcolutites rogenques i guixos. Per sobre s'han anat fen palesos els trams carbonatats del Muschelkalk Superior. Alhora que per sota, haurem vist (a la Serra de Cabrafiga) afloraments dels trams carbonatats del Muschelkalk Inferior.

En aquest indret hi va haver-hi una antiga explotació dels nivells de guixos del Muschelkalk Mig, dels quals ja n'hem parlat en tot aquest recorregut, des de l'inici de l'itinerari. Tot i que sovint s'havien fet palesos els nivells dels guixos, sols hem vist la present explotació, ja que aquí tenen una potencia d'uns 10 - 15 metres segons els llocs. Al respecte, cal dir que hi ha diferents explotacions. (fotografía 4).

Per altra banda, en aquest indret hi ha uns interessant $\mathrm{i}$ antics forns de guix, dedicats a l'obtenció del guix de construcció. No cal dir que aquests elements, formen part del patrimoni miner de la comarca del Baix Camp. Creiem que caldria una certa protecció d'aquests elements del patrimoni preindustrial. Tot i així, no descartem que hi hagi altres forns similars per aquesta zona. (fotografía 5 i 6 ). 


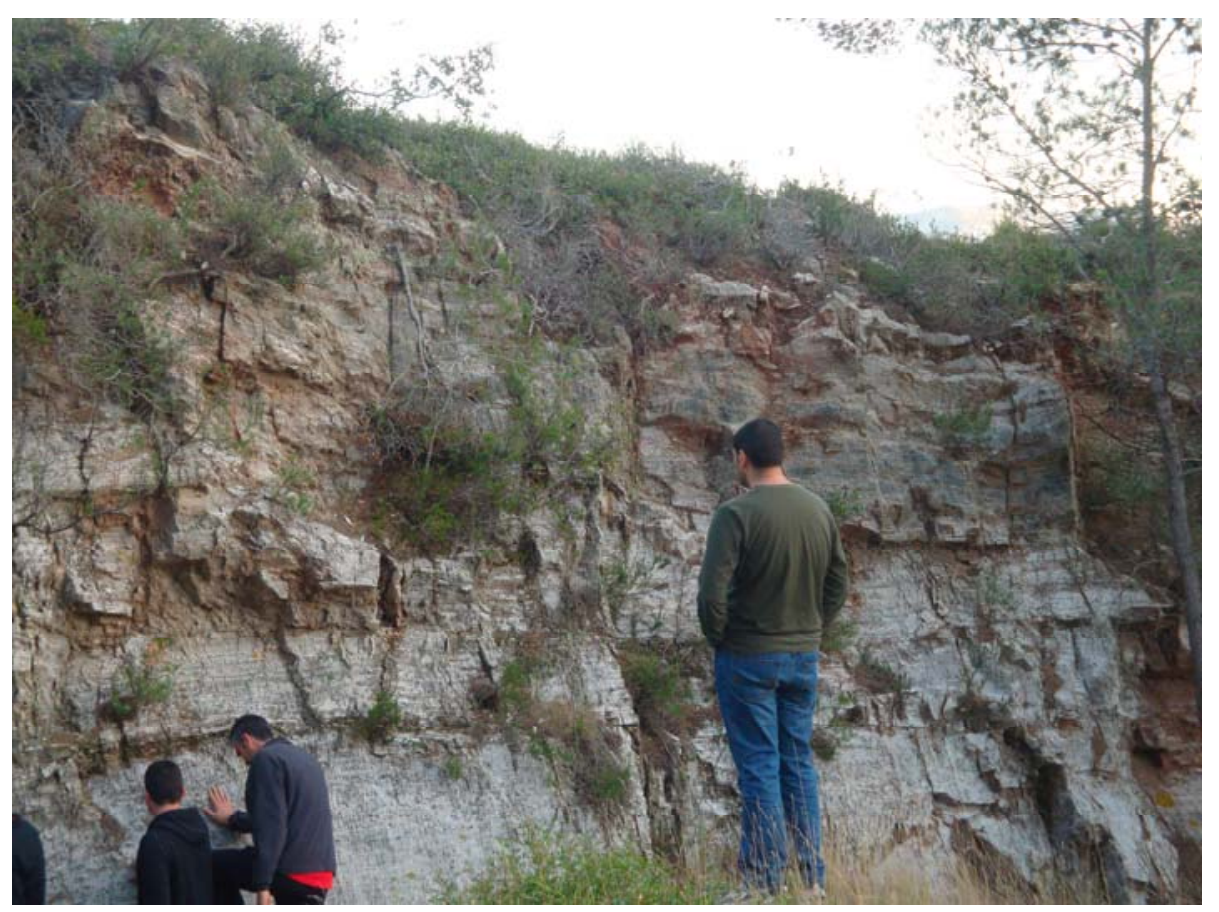

Fotografia 4. Guixera i aflorament dels guixos. Coll del Guix
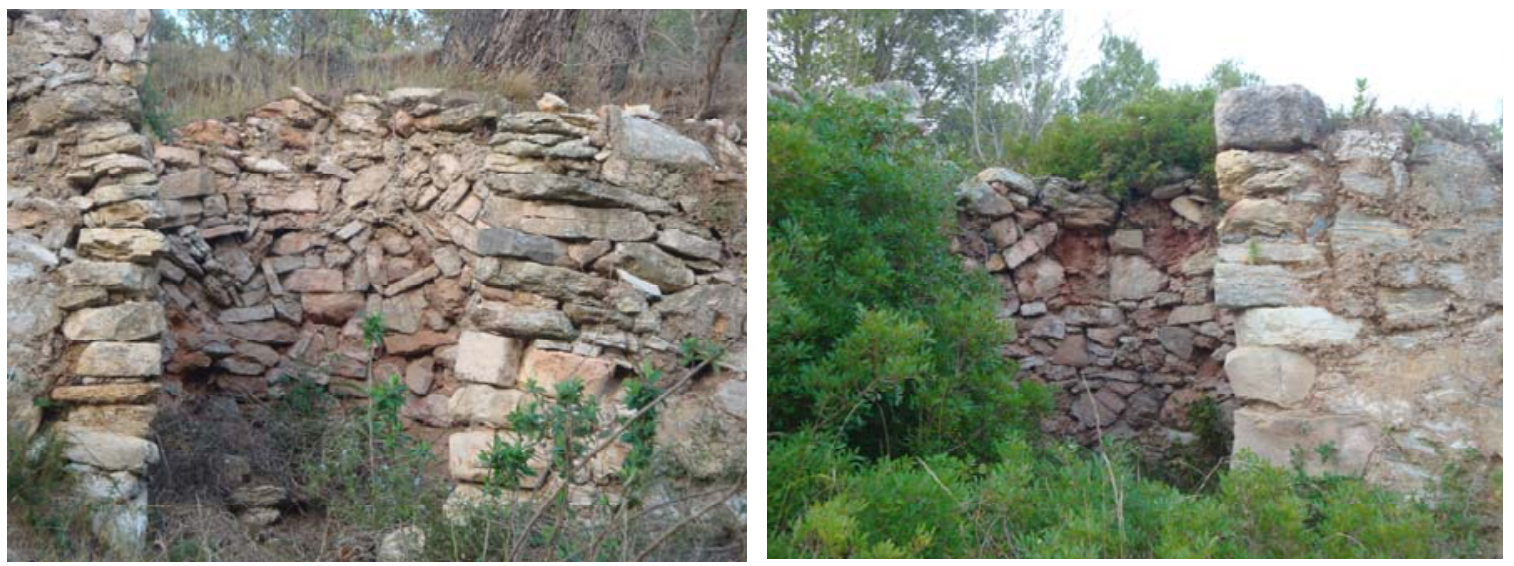

Fotografies 5 i 6 . Forns de Guix. Coll del Guix. Carretera de Pratdip a Colldejou 


\subsection{Parada 6. TRENCALL DE LA CARRETERA AL COLL DE LA LLENA, (terme de Colldejou, comarca del Baix Camp). (Full 472).}

Des de la parada anterior, cal continuar per la carretera que es dirigeix cap al Coll de la Llena, tot anant cap a Colldejou,. Així, s'ha d'arribar quasi fins a la cruilla amb la carretera T-322 I TV-3001. Malgrat això, es millor fer l'aturada a uns $150 \mathrm{~m}$ del trencall, tot anant cap a Colldejou. Així, des de la parada anterior, s'haurà efectuat un recorregut proper als $2 \mathrm{Km}$.

Després de la parada anterior, s'han continuat trobant, els materials triàsics esmentats a les aturades anteriors. Aquests materials corresponen als els nivells rogencs del Muschelkalk Mig, constituïts per calcolutites, amb abundants intercalacions guixoses, com les que es troben a I'indret on efectuem la present aturada. (fotografía 7).

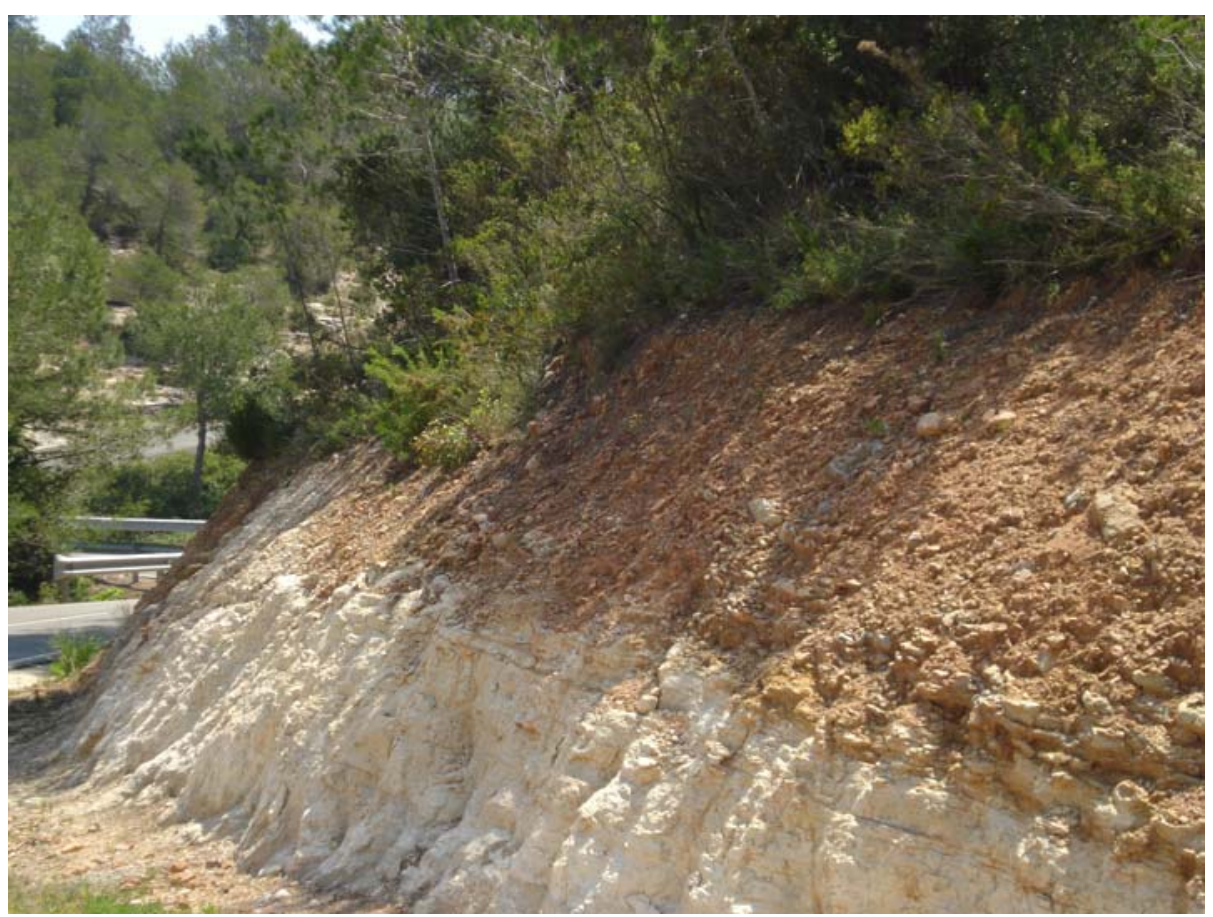

Fotografia 7. El Muschelkalk Mig (nivells de calcolutites rogenques), prop de la cruilla de la carretera a Pratdip pel Coll de Llena

Tot i així, al Sud d'on ara ens trobem, apareixen els trams carbonatats del Muschelkalk Inferior, els quals constitueixen els relleus de la Serra de Cabrafiga, que ja hem esmentat a la parada anterior. Per d'altra banda, des d'aquest lloc, i mirant cap al proper poble de Colldejou, es pot veure el relleu "en cuesta", dibuixat pels dos trams carbonatats del Muschelkalk (el Inferior i el Superior), entre els quals es troba el Muschelkalk Mig.

També es pot veure la plana que forma el Keuper, situat per sobre del Muschelkalk Superior. Per d'altra banda, tot mirant cap al Nord (o cap al NNW), es poden veure els relleus de la Mola de Colldejou, on afloren els materials del Juràssic, situats per sobre dels del Keuper. 


\subsection{Parada 8. IMMEDIACIONS DEL COLL DE JOU i DEL COLLET ROIG, (termes de Colldejou i de la Torre de la Fontaubella, comarques del Baix Camp i del Priorat, respectivament). (Full 472).}

Des de la parada anterior, cal continuar per la carretera T-322 / TV-3001, primer cap a I'immediat poble de Colldejou, i posteriorment cap al de la Torre de la Fontaubella. En aquest recorregut, ens caldrà arribar fins al Coll de Jou, per tal de fer aquí la present aturada.; tot i que aquesta la farem a cavall d'aquest coll i del proper Collet Roig. Així, des de la parada anterior, $s^{\prime}$ haurà efectuat un recorregut de prop de $6 \mathrm{Km}$, per tal d'arribar a l'indret de la present aturada.

En aquest recorregut, s'han anat tallant, en quasi tot el recorregut, els materials rogencs del Muschelkalk Mig, els quals es troben constituïts per nivells de calcolutites i de guixos. Per sobre $d^{\prime}$ aquests materials s' han trobat els nivells calcaris del Muschelkalk Superior (com a l'indret on es troba el poble de Colldejou). Aquests nivells es troben constituïts per nivells carbonatats de calcàries i de dolomies.

Per altra banda, molt sovint, s'observa com aquestes calcàries (de vegada molt margoses i de molt fina estratificació) es troben molt replegades i també fracturades. (fotografia 8).

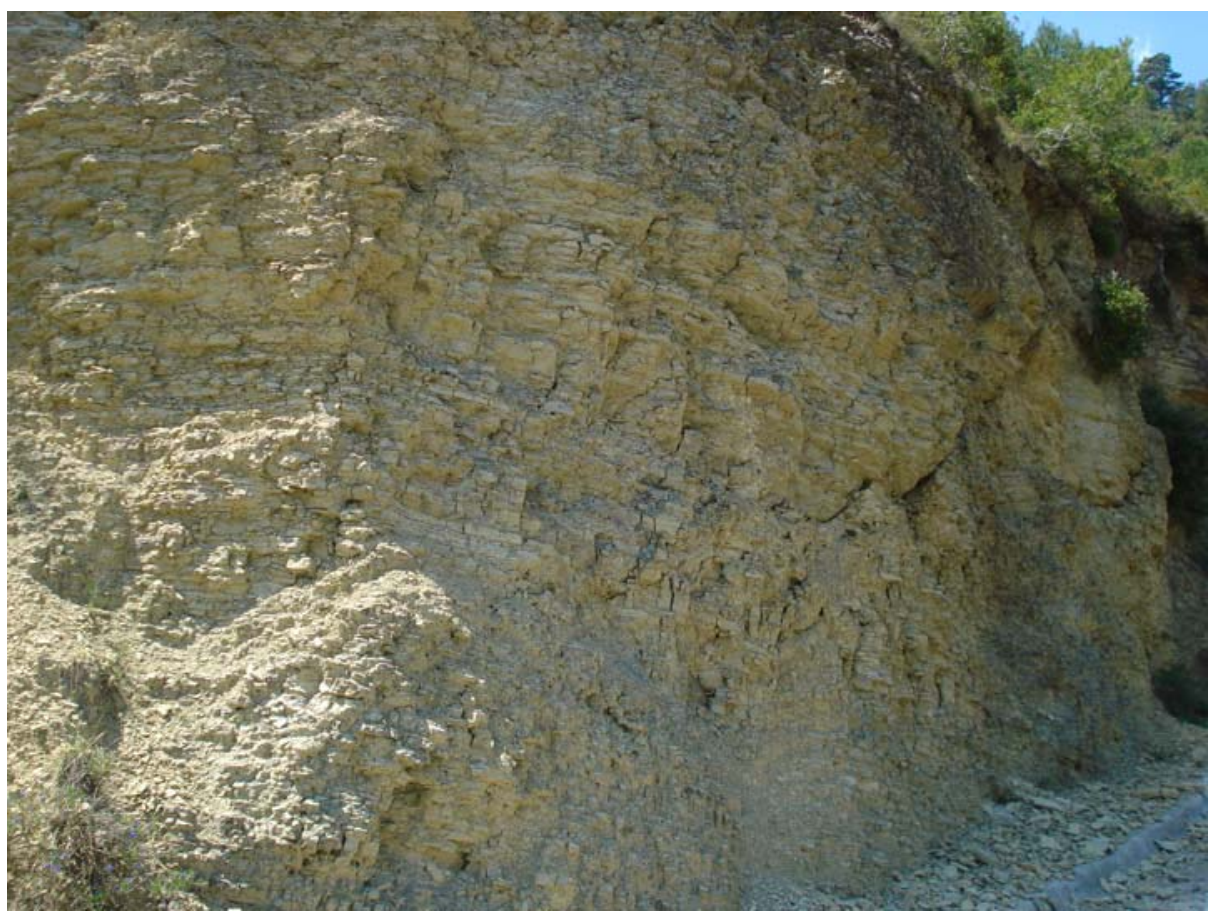

Fotografia 8. Calcaries margoses del Muschelkalk Superior

En arribar a l'indret de la parada, s'observa com els materials situats a la dreta de la carretera, i per sota de la mateixa, que pertanyen al Muschelkalk Inferior, presenten un fort cabussament cap a l'Oest. També s'observa que prop del coll s'estrenyen els materials del Muschelkalk Mig.

Mes enllà del coll, en un altre collet (el Collet Roig), situat a uns $0^{\prime} 4 \mathrm{Km}$, s'observa l'existència d'una falla, la qual provoca aquest pinçament dels materials rogencs. Inclús, pot observar-se com al segon coll (al collet), desapareixen pràcticament aquests materials del Muschelkalk Mig. (esquema 1). 
Un esquema seriat, de Sud a Nord, d'aquesta falla, és el següent:

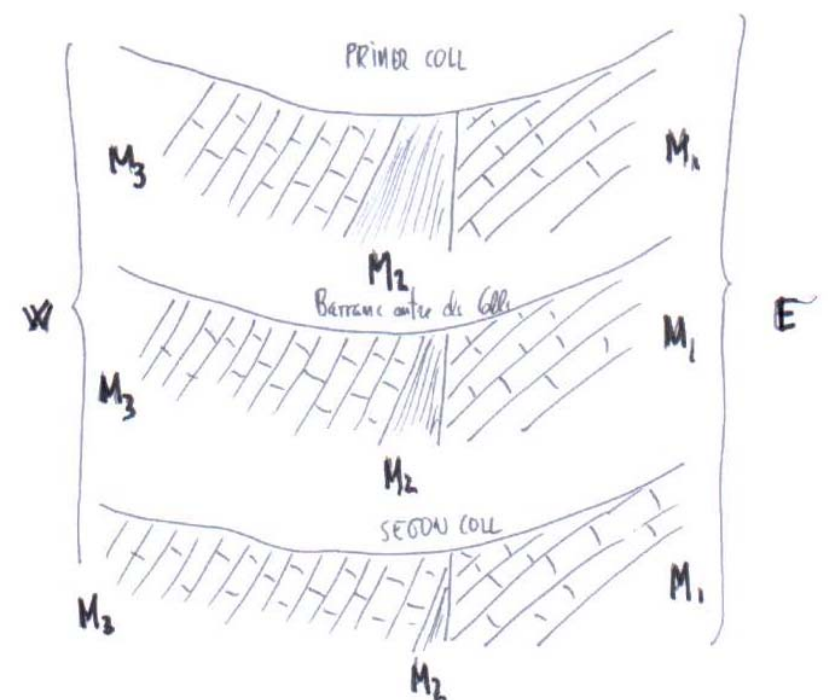

Esquema 1. Esquema del autor (MATA - PERELLÓ 2008b)

En aquest indret finalitza el recorregut de l'itinerari

\section{Bibliografia}

GUIMERÀ, J. et altri /1992).- Geologia (II), Història Natural dels Països Catalans, Vol.2, 547 pag. Enciclopèdia Catalana, S,A, Barcelona.

IGME (1978a).- Mapa Geológico de España, a escala 1:50.000, 2a Serie. Full i memória nº 471 (Mora d’Ebre). Inst. Geol Minero de España. Minist. Indústria. Madrid.

IGME (1978b).- Mapa Geológico de España, a escala 1:50.000, 2ª Serie. Full i memória nº 472 (Reus). Inst. Geol Minero de España. Minist. Indústria. Madrid.

IGME (1978c).- Mapa Geológico de España, a escala 1:50.000, $2^{\text {a }}$ Serie. Full i memória nº 472 (Reus). Inst. Geol Minero de España. Minist. Indústria. Madrid

MATA-PERELLÓ, J.M. (1991).- Els Minerals de Catalunya. Institut d'Estudis Catalans. Arxius de la Secció de Ciències, T.XLVIII, 506 pag. Barcelona.

MATA-PERELLÓ, J.M. (1996a).- Itinerari geologico-mineralògic pel Priorat i pel Baix Camp: de Mont-roig del Camp a Falset i a Tivissa. Inèdit, 12 pàgines, Manresa.

MATA-PERELLÓ, J. M. (1996b).- Itinerari geològico - mineralògic per les comarques del Baix Camp, Priorat i per la Ribera d'Ebre: des de Mont-roig del Camp a Tivissa, per Colldejou i per Marçà. Inèdit, 11 pag. Manresa. 
MATA-PERELLÓ, J. M. (1997).- Recerca geològica i mineralògica per les comarques del Baix Camp i del Priorat: des de Mont-roig del Camp a Falset, per Pradell de la Teixeta. Inèdit, 16 pag. Manresa.

MATA-PERELLÓ, J. M. (1998).- Recorregut de recerca geològica i mineralògica per les comarques del Baix Camp, Priorat i per la Ribera d'Ebre: des de Montbrió del Camp cap a Tivissa, per Colldejou i per Falset. Inèdit, 18 pag. Manresa.

MATA-PERELLÓ, J. M. (2000).- Recorregut de recerca geològica i mineralògica per les comarques del Baix Camp, de la Ribera d'Ebre i del Priorat: des de Reus i Mont-roig del Camp a Tivissa i a Falset, Inèdit, 16 pag. Manresa.

MATA-PERELLÓ, J. M. (2001).- Recorregut de recerca geològica i mineralògica per les comarques del Baix Camp i de la Ribera d'Ebre: des d'Hospitalet de l'Infant a Pratdip i a Llaberia, i des de Tivissa a Marçà i a Mont-roig del camp. Inèdit. 20 pag. Manresa.

MATA-PERELLÓ, J. M. (2004a).- Recerca geològica i mineralògica per les comarques del Baix Camp i del Priorat: des de Mont-roig del Camp a Pradell de la Teixeta, a Falset i a Bellmunt, Inèdit 14 pag. Manresa.

MATA-PERELLÓ, J. M. (2004b).- Recorregut de recerca geològica i mineralògica per les comarques del Baix Camp i del Priorat: des de Montbrió del Camp a Falset, per Colldejou i per Pradell de la Teixeta. Inèdit. 12 pag. Manresa.

MATA-PERELLÓ, J. M. (2008a).- Recorregut de recerca geológica i mineralògica per les comarques del Baix Camp i del Priorat: des de Montbrió de Camp a Mont-roig del Camp, Colldejou, la Torre de la Fontaubella i a Marçà. Inèdit. 16 pag. Manresa.

MATA-PERELLÓ, J. M. (2008b).- Recorregut de recerca geològica i mineralògica per les comarques del Baix camp i del Priorat: des de Mont-roig del Camp a Colldejou i a Marçà. Inèdit. 10 pàgines. Manresa.

MATA-PERELLÓ, J. M. (2011a).- Recorregut de recerca geològica i mineralògica per la comarca del Priorat: des del Coll de la Teixeta i Pradell a Falset i a Bellmunt del Priorat. Inèdit. 10 pàgines. Manresa.

MATA-PERELLÓ, J. M. (2011b).- Recorregut de recerca geològica i mineralògica per les comarques del Baix Camp i del Priorat: des de Mont-roig del camp a Colldejou, la Torre de la Fontaubella, Pradell de la Teixeta i a Falset. Inèdit. 10 pàgines. Manresa.

MATA-PERELLÓ, J. M. (2011c).- Recorregut de recerca geològica i mineralògica per les comarques del Baix Camp i del Priorat: des del Coll Roig de Pratdip, a Pratdip, Colldejou, Torre de la Fontaubella i a Falset. Inèdit. 12 pàgines. Manresa.

MATA-PERELLÓ, J. M. (2012).- Recorregut de recerca geològica i mineralògica per les comarques del Priorat, de la Ribera d'Ebre i del Baix Camp: des de Falset a Mora la Nova, Tivissa i a Llaberia. Inèdit. 12 pàgines. Manresa.

MELGAREJO i DRAPER, J.C. (1992).- Estudio geológico y metalogenético del paleozoico del sur de las Cordilleras Costeras Catalanas. Memórias del Instituto Tecnològico y Geo-Minero de España, tomo 103, 605 pag. Madrid.

RIBA, O. et altri (1976).- Geografia Física dels Països Catalans. Edit. Ketres, 254 pàgines. Barcelona. 